\title{
Research in the Laboratory of Supramolecular Chemistry: Functional Nanostructures, Sensors, and Catalysts
}

\author{
Kay Severin*
}

Abstract: This article summarizes research activities in the Laboratory of Supramolecular Chemistry (LCS) at the EPFL. Three topics will be discussed: a) the construction of functional nanostructures by multicomponent self-assembly processes, b) the development of chemosensors using specific receptors or ensembles of crossreactive sensors, and c) the investigation of novel synthetic procedures with organometallic catalysts.

Keywords: Catalysis · Organometallic complexes · Pattern recognition · Nanostructures · Self-assembly Sensors

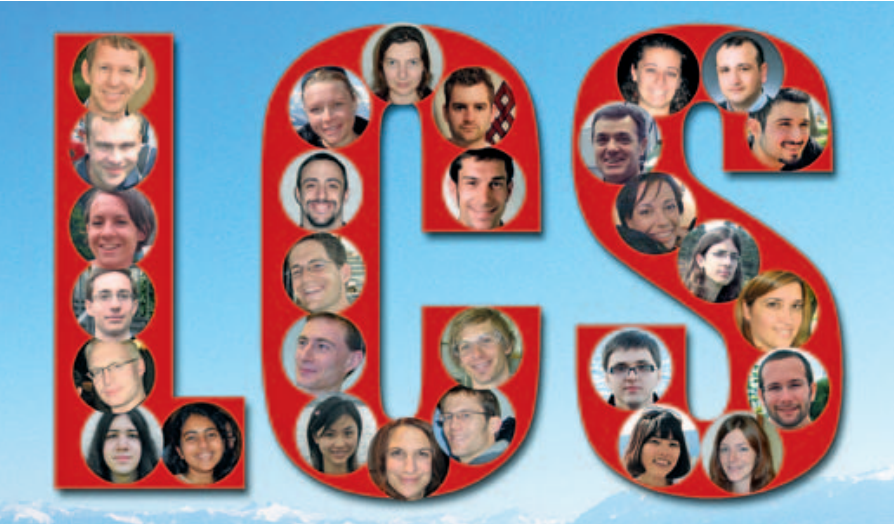

Present and recent members of the Laboratory of Supramolecular Chemistry (LCS).

The Laboratory of Supramolecular Chemistry (LCS) at the EPFL was established in 2001. In the same year, we reported the synthesis of a Ru-based metallamacrocycle which displayed high affinity and selectivity for small alkali metal ions. ${ }^{[1]}$ This publication marked the starting point for a central topic in our laboratory: the utilization of self-assembly processes to create complex molecular structures with interesting properties and functions.

Transition metal complexes, in particular organometallic halfsandwich com-

${ }^{\star}$ Correspondence: Prof. K. Severin

Ecole Polytechnique Fédérale de Lausanne Institut des Sciences et Ingénierie Chimiques $\mathrm{BCH}$-LCS

1015 Lausanne

Tel.: +41216939302

Fax: +41216939305

E-mail: kay.severin@epfl.ch

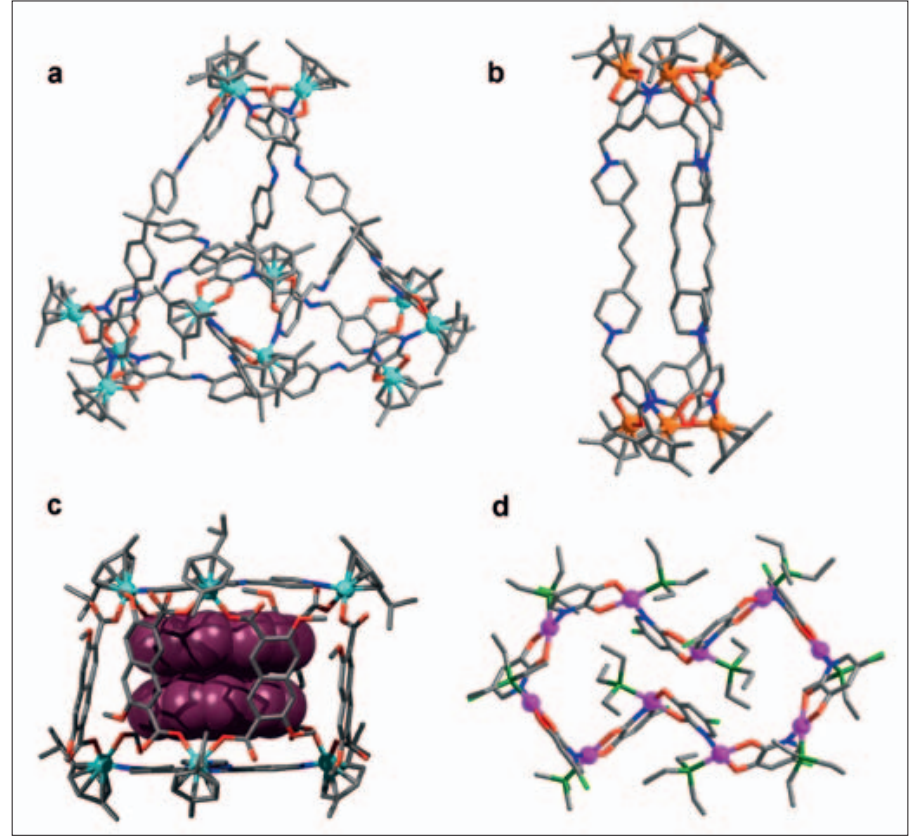

Fig. 1 Molecular nanostructures based on transition metal complexes: a) a tetrahedral Ru complex, b) a cylindrical Rh complex, c) a prismatic $R u$ complex with encapsulated coronene guest molecules, and d) a decanuclear Pd complex. plexes, ${ }^{[2]}$ are versatile building blocks for the construction of complex nanostructures. Initially, our efforts focused on the synthesis of macrocyclic complexes, ${ }^{[3]}$ and in recent years, this has evolved to the exploration of three-dimensional cage structures. ${ }^{[4]}$ The solid-state structures of some selected examples are depicted in Fig. 1.

A goal our lab is working towards is determining the best strategies to synthesize complex nanostructures from multiple, and chemically distinct building blocks. One approach, which has given promising results, is the simultaneous utilization of dynamic covalent chemistry with metalligand interactions in an orthogonal fash- ion. ${ }^{[5]}$ This methodology has allowed us to synthesize complex cage structures with up to 12 metal centers in a stereoselective fashion. Furthermore, we are interested in the dynamics of multicomponent aggregates. Dynamic mixtures of self-assembled compounds represent molecular networks, which may adapt to external stimuli by reequilibration. We observed that the adaptation process is strongly dependent on the boundary condition of the experiment (concentrations, network topology etc.).[6]

Similar to metal-ligand interactions, boron-oxygen and boron-nitrogen bonds can be thermodynamically highly stable but kinetically labile. This characteris- 


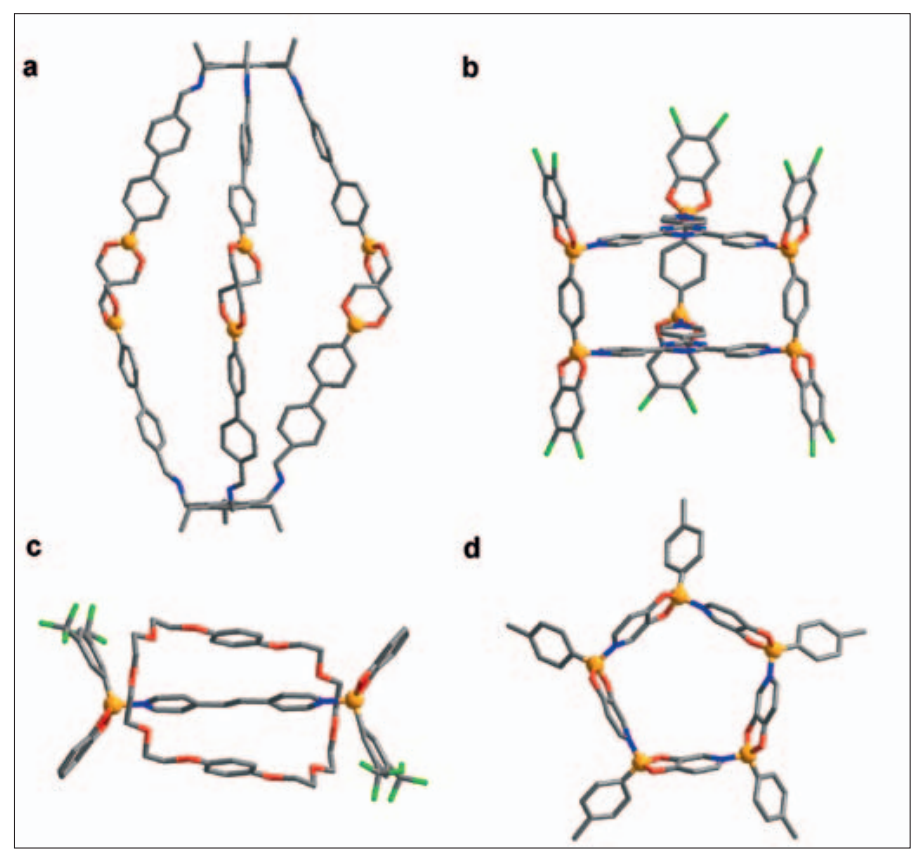

Fig. 2. Molecular nanostructures based on boronic acids: a) a cylindrical cage obtained by ball milling, b) a prismatic cage, c) a rotaxane, and d) a pentameric macrocycle. tic prompted us to explore the utilization of boronate esters and their adducts with $\mathrm{N}$-donor ligands in structural supramolecular chemistry. ${ }^{[7]}$ Using multicomponent condensation reactions, we have been able to access different molecular architectures such as macrocycles, ${ }^{[8]}$ cages, ${ }^{[9]}$ rotaxanes, ${ }^{[10]}$ dendrimers, ${ }^{[11]}$ and polymeric networks (Fig. 2). ${ }^{[12]}$

Some of the metal-containing nanostructures that we have synthesized were found to be potent and selective receptors for small ions such as alkali metal cations, fluoride or orthophosphate. ${ }^{[1,4 c, 13]}$ In view of the pharmacological importance of $\mathrm{Li}^{+}$, we have optimized the affinity, selectivity, and solubility of the lithium receptors. ${ }^{[14]}$ This research cumulated in the development of a simple assay for the fluorimetric detection of $\mathrm{Li}^{+}$in aqueous solution. ${ }^{[15]}$

Using metal-based receptors, we have also devised assays for the selective detection of chloride ${ }^{[16]}$ as well as peptides containing histidine residues at the N-terminus. ${ }^{[17]}$ For many biologically important analytes, it is intrinsically difficult to generate selective receptors. An inter-

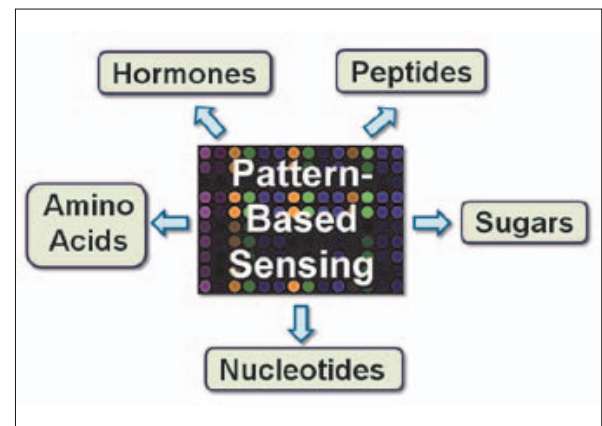

Fig. 3. Pattern-based sensing methods are used for the detection of biologically interesting analytes. esting alternative to chemosensors based on selective receptors is the utilization of pattern-based sensing methods. In these sensors, an ensemble of cross-reactive sensors provides a characteristic pattern for the analyte. The pattern can be linked to the identity, quantity, or purity of the analyte. We have used pattern-based sensing schemes for the analysis of amino acids, ${ }^{[18]}$ peptides, ${ }^{[19]}$ antibiotics, ${ }^{[20]}$ nucleotides, ${ }^{[21]}$ and glycosaminoglycans ${ }^{[22]}$ (Fig. 3).

In addition to projects in structural supramolecular chemistry and sensing, the LCS has an active research program in organometallic synthesis and catalysis. The synthetic efforts have focused on the development of novel procedures for the preparation of bimetallic complexes, [23] complexes with unusual $\pi$-ligands, ${ }^{[24]}$ and the activation of small molecules such as $\mathrm{N}_{2} \mathrm{O}$.

With respect to catalysis, we have primarily investigated atom transfer radical addition (ATRA) and polymerization (ATRP) reactions. Initially, much effort was devoted to the development of more efficient catalysts ${ }^{[25]}$ as well as un-

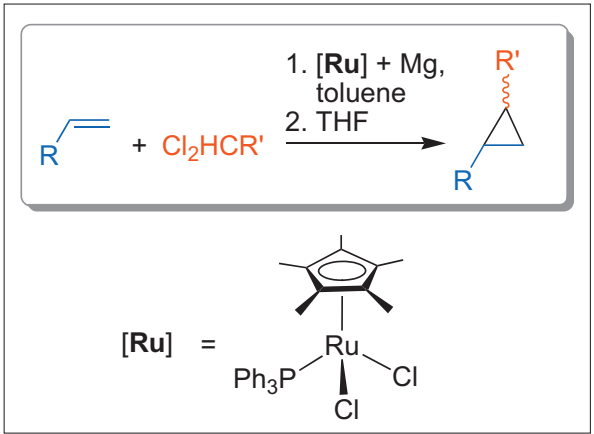

Scheme 1. One-pot synthesis of cyclopropanes by Ru-catalyzed ATRA-dechlorination reactions. derstanding the reaction mechanism. [26] Additives such as azobis(isobutyronitrile) (AIBN), ${ }^{[27]} \mathrm{Mg}^{\left[{ }^{[28]}\right.}$ and $\mathrm{Mn}^{[29]}$ were found to increase the catalyst performance dramatically. More recently, we are increasingly exploring synthetic applications. For example, we have reported a new method for the synthesis of cyclopropanes, which avoids the utilization of problematic diazo compounds. ${ }^{[30]}$ Instead, stable and readily accessible chlorinated compounds are employed (Scheme 1). This one-pot procedure is applicable to a wide range of substrates and the reactions can be performed in an inter- and intramolecular fashion.

\section{Acknowledgments}

The work of the LCS has been supported by the Swiss National Science Foundation, by European Union FP6 and FP7 projects, by COST, by the Claude and Giuliana foundation, by the CTI, by the Swiss State Secretariat for Education and Research, and by the EPFL. I'm very grateful to everyone who contributed to the projects.

Received: May 26, 2011

[1] H. Piotrowski, K. Polborn, G. Hilt, K. Severin, J. Am. Chem. Soc. 2001, 123, 2699.

[2] Reviews: a) T. B. Rauchfuss, K. Severin, in 'Organic Nanostructures', Eds. J. L. Atwood, J. W. Steed, Wiley-VCH, 2008, 179; b) K. Severin, Chem. Commun. 2006, 3859; c) K. Severin, Coord. Chem. Rev. 2003, 245, 3.

[3] a) T. Brasey, R. Scopelliti, K. Severin, Inorg. Chem. 2005, 44, 160; b) M.-L. Lehaire, L. Herdeis, R. Scopelliti, K. Polborn, P. Mayer, K. Severin, Inorg. Chem. 2004, 43, 1609; c) T. Brasey, A. Buryak, R. Scopelliti, K. Severin, Eur. J. Inorg. Chem. 2004, 964

[4] a) S. Mirtschin, A. Slabon-Turski, R. Scopelliti, A. H. Velders, K. Severin, J. Am. Chem. Soc. 2010, 132, 14004; b) C. Olivier, R. Scopelliti, K. Severin, Eur. J. Inorg. Chem. 2009, 207; c) S. Mirtschin, E. Krasniqi, R. Scopelliti, K. Severin, Inorg. Chem. 2008, 47, 6375; d) C. Olivier, R. Scopelliti, K. Severin, Inorg. Chem. 2008, 47, 4454; e) T. Brasey, R. Scopelliti, K. Severin, Chem. Commun. 2006, 3308.

[5] a) A. Granzhan, C. Schouwey, T. RiisJohannessen, R. Scopelliti, K. Severin, J. Am. Chem. Soc. 2011, 133, 7106; b) A. Granzhan, T. Riis-Johannessen, K. Severin, Angew. Chem. Int. Ed. 2010, 49, 5515; c) N. Christinat, R. Scopelliti, K. Severin, Angew. Chem. Int. Ed. 2008, $47,1848$.

[6] a) Z. Grote, R. Scopelliti, K. Severin, Eur. J. Inorg. Chem. 2007, 694; b) I. Saur, R. Scopelliti, K. Severin, Chem. Eur. J. 2006, 12, 1058; c) I. Saur, K. Severin, Chem. Commun. 2005, 1471; d) K. Severin, Chem. Eur. J. 2004, 10, 2565; e) Z. Grote, R. Scopelliti, K. Severin, Angew. Chem. Int. Ed. 2003, 42, 3821.

[7] K. Severin, Dalton Trans. 2009, 5254.

[8] a) N. Christinat, R. Scopelliti, K. Severin, Angew. Chem. Int. Ed. 2008, 47, 1848; b) N. Christinat, R. Scopelliti, K. Severin, Chem. Commun. 2004, 1158.

[9] B. Içli, N. Christinat, J. Tönnemann, C. Schüttler, R. Scopelliti, K. Severin, J. Am. Chem. Soc. 2009, 131, 3154.

[10] N. Christinat, R. Scopelliti, K. Severin, Chem. Commun. 2008, 3660.

[11] N. Christinat, R. Scopelliti, K. Severin, J. Org. Chem. 2007, 72, 2192

[12] a) E. Sheepwash, V. Krampl, R. Scopelliti, O. 
Sereda, A. Neels, K. Severin, Angew. Chem. Int. Ed. 2011, 50, 3034; b) N. Christinat, E. Croisier, R. Scopelliti, M. Cascella, U. Röthlisberger, K. Severin, Eur. J. Inorg. Chem. 2007, 5177.

[13] a) C. Olivier, Z. Grote, E. Solari, R. Scopelliti, K. Severin, Chem. Commun. 2007, 4000; b) M.-L. Lehaire, R. Scopelliti, H. Piotrowski, K. Severin, Angew. Chem. Int. Ed. 2002, 41, 1419; c) H. Piotrowski, G. Hilt, A. Schulz, P. Mayer, K. Polborn, K. Severin, Chem. Eur. J. 2001, 7, 3197.

[14] a) S. Rochat, K. Severin, Org. Biomol. Chem. 2009, 7, 1147; b) Z. Grote, H.-D. Wizemann, R. Scopelliti, K. Severin, Z. Anorg. Allg. Chem. 2007, 633, 858; c) Z. Grote, R. Scopelliti, K. Severin, J. Am. Chem. Soc. 2004, 126, 16959 ; d) Z. Grote, M.-L. Lehaire, R. Scopelliti, K. Severin, J. Am. Chem. Soc. 2003, 125, 13638 ; e) H. Piotrowski, K. Severin, Proc. Natl. Acad. Sci. USA 2002, 99, 4997.

[15] J. Gao, S. Rochat, X. Qian, K. Severin, Chem. Eur. J. 2010, 16, 513.

[16] a) T. Riis-Johannessen, K. Severin, Chem. Eur. J. 2010, 16, 8291; b) T. Riis-Johannessen, K. Schenk, K. Severin, Inorg. Chem. 2010, 49, 9546.

[17] A. Buryak, K. Severin, Angew. Chem. Int. Ed. 2004, 43, 4771.

[18] A. Buryak, K. Severin, J. Am. Chem. Soc. 2005, 127,3700 .

[19] a) S. Rochat, J. Gao, X. Qian, F. Zaubitzer, K. Severin, Chem. Eur. J. 2010, 16, 104; b) S. Rochat, K. Severin, J. Comb. Chem. 2010, 12, 595 ; c) F. Zaubitzer, T. Riis-Johannessen, K. Severin, Org. Biomol. Chem. 2009, 7, 4598.

[20] F. Zaubitzer, A. Buryak, K. Severin, Chem. Eur. J. 2006, 12, 3928.

[21] a) J. Gao, A. Granzhan, X. Qian, K. Severin, Chem. Commun. 2010, 46, 5515; b) A. Buryak, F. Zaubitzer, A. Pozdnoukhov, K. Severin, J. Am. Chem. Soc. 2008, 130, 11260; c) A. Buryak, A. Pozdnoukhov, K. Severin, Chem. Commun. 2007, 2366.

[22] P.-K. Müller-Graf, H. Szelke, K. Severin, R. Krämer, Org. Biomol. Chem. 2010, 8, 2327.

[23] a) E. Solari, S. Gauthier, R. Scopelliti, K. Severin, Organometallics 2009, 28, 4519; b)
C. Albrecht, S. Gauthier, J. Wolf. R. Scopelliti, K. Severin, Eur. J. Inorg. Chem. 2009, 1003; c) J. Wolf, K. Thommes, O. Briel, R. Scopelliti, K. Severin, Organometallics 2008, 27, 4464; d) L. Quebatte, R. Scopelliti, K. Severin, Eur. J. Inorg. Chem. 2006, 231; e) S. Gauthier, R. Scopelliti, K. Severin, Organometallics 2004, 23, 3769; f) S. Gauthier, L. Quebatte, R. Scopelliti, K. Severin, Chem. Eur. J. 2004, 10, 2811.

[24] a) B. Dutta, B. F. E. Curchot, P. Campomanes, E. Solari, R. Scopelliti, U. Rothlisberger, K. Severin, Chem. Eur. J. 2010, 16, 8400; b) D. Rechavi-Robinson, R. Scopelliti, K. Severin, Organometallics 2008, 27, 5978; c) B. Dutta, C. Scolaro, R. Scopelliti, P. J. Dyson, K. Severin, Organometallics 2008, 27, 1355; d) B. Dutta, E. Solari, R. Scopelliti, K. Severin, Organometallics 2008, 27, 423; e) B. Dutta, E. Solari, S. Gauthier, R. Scopelliti, K. Severin, Organometallics 2007, 26, 4791; f) S. Gauthier, E. Solari, R. Scopelliti, B. Dutta, K. Severin, Chem. Commun. 2007, 1837.

[25] a) M. Haas, E. Solari, Q. T. Nguyen, S. Gauthier, R. Scopelliti, K. Severin, Adv. Synth. Catal. 2006, 348, 439; b) L. Quebatte, E. Solari, R. Scopelliti, K. Severin, Organometallics 2005, 24, 1404; c) L. Quebatte, M. Haas, E. Solari, R. Scopelliti, Q. T. Nguyen, K. Severin, Angew. Chem. Int. Ed. 2005, 44, 1084; d) L. Quebatte, R. Scopelliti, K. Severin, Angew. Chem. Int. Ed. 2004, 43, 1520.

[26] M. A. Fernández-Zúmel, K. Thommes, G. Kiefer, A. Sienkiewicz, K. Pierzchala, K. Severin, Chem. Eur. J. 2009, 15, 11601.

[27] L. Quebatte, K. Thommes, K. Severin, J. Am. Chem. Soc. 2006, 128, 7440.

[28] K. Thommes, B. Içli, R. Scopelliti, K. Severin, Chem. Eur. J. 2007, 13, 6899.

[29] M. A. Fernández-Zúmel, C. Buron, K. Severin, Eur. J. Org. Chem. 2011, 2272.

[30] K. Thommes, G. Kiefer, R. Scopelliti, K. Severin, Angew. Chem. Int. Ed. 2009, 48, 8115. 